\title{
Optimization and Partial Characterization of a Putative Probiotic Bacterium Antagonistic to Vibrios in Shrimp Larval Rearing System
}

\author{
Abdullah Sarker ${ }^{1}$, Shafiqur Rahman ${ }^{1}$, Shakila N. Khan ${ }^{1}$, M. Niamul Naser ${ }^{2}$ \\ and Muhammad Manjurul Karim ${ }^{1}$ \\ ${ }^{1}$ Department of Microbiology, Faculty of Biological Sciences, University of Dhaka, Dhaka 1000, Bangladesh \\ ${ }^{2}$ Department of Zoology, Faculty of Biological Sciences, University of Dhaka, Dhaka 1000, Bangladesh
}

\begin{abstract}
Organic aquaculture utilizing probiotics for disease control and bioremediation has gained global acceptance in recent years. A preliminary study was conducted to isolate indigenous bacteria antagonistic to pathogenic vibrios as putative probiotics for shrimp hatcheries and grow-out systems. These efforts resulted in the isolation of a Gram-positive bacilli after screening thirty one water samples, collected from the coastal areas of the Bay of Bengal. This probiont, identified as Bacillus licheniformis exhibited vibriocidal activity in vitro against $60 \%$ of the Vibrio species isolated from the same water samples based on broad spectrum antagonistic and hydrolytic properties. In this study, we looked into the effects of $\mathrm{pH}$, temperature, salinity, surfactants (Triton X114, Tween 80 and SDS) and EDTA on the vibriocidal property of the cell-free supernatant of the probiotic and observed that the antagonistic property was refractory to the surfactants used. The optimum activity of the cell-free supernatant was observed at $30^{\circ} \mathrm{C}$, below and above which there was a marked decline in the inhibition. Neutral and alkaline $\mathrm{pH}$ ranges favored the antagonistic property while it was negligible at acidic ranges. The metal chelator EDTA nullified the antagonistic property at $0.01 \mathrm{mM}$ concentration, the lowest tested, indicating the presence of a metal active group in the active fraction. The study suggests the potential of the selected bacterial isolate as a putative, antagonistic probiotic useful in the aquaculture systems of the tropics considering its broad antagonistic activity, higher activity in the neutral and alkaline $\mathrm{pH}$ and optimum activity at $30^{\circ} \mathrm{C}$. Efforts are underway to purify and characterize the antagonistic compound in the cell-free supernatant.
\end{abstract}

Key words: Probiotic, vibrios, Bacillus, shrimp, cell-free supernatant

\section{INTRODUCTION}

Vibriosis is probably the major disease afflicting fish, crustaceans, and mollusk aquaculture around the world. A crisis in the shrimp industry over the last few years is due to largely to an increase in virulence of pathogens, especially Vibrio spp, together with white spot viruses. Usually, the disease is treated rather than the underlying cause. The interactions of microbes, animals and their environment under the stress of commercial production, and the use of antimicrobial chemicals, especially antibiotics and

Correspondence to:

M. Manjurul Karim

E-ail: manjur@univdhaka.edu chlorine, have led to the emergence of more virulent pathogens. ${ }^{1-3}$ This not only poses a threat to the food safety in shrimp but also jeopardizes this prospective industry from earning foreign currency for the national economy. In Bangladesh, exports of fresh water shrimp, the second biggest foreign currency earner, to the European Union face a suspension due to the detection of health hazardous antibioticnitrofuran since January 2009. ${ }^{4}$ The use of beneficial bacteria (probiotics) to displace pathogens by competitive processes and to inhibit their proliferation is a better remedy than administering antibiotics. $^{5-7}$ 
The isolation of probiotic bacteria from local environment of Bangladesh was first reported in $2008^{8}$ in a study conducted by these authors. The study discovered some potential probionts from the shrimp hatcheries and grow-out systems of the coastal areas of the Bay of Bengal that showed zones of clearance against pathogenic vibrios, isolated from the same water samples. Two bacteria, identified as Bacillus sp. and Pseudomonas sp. exhibited vibriocidal activity in vitro against $60 \%$ and $30 \%$ of the Vibrio species respectively. The advantage of Bacillus as a probiotic candidate is that it constitutes a large part of the microflora of the gills, skin and intestinal tracts of shrimps. ${ }^{9}$ Further, Gram positive bacteria like Bacillus are unlikely to use genes for antibiotic resistance or virulence from the vibrios or related Gram negative bacteria thereby, makes it an attractive probiotic candidate in the shrimp culture ponds. ${ }^{10}$ This study therefore characterizes the maximum vibriocidal potency and growth pattern of the isolated Bacillus sp. in different environmental conditions, and thereafter optimizes its spectrum of antagonism as its probiotic potential.

\section{MATERIALS AND METHODS}

Identification of the probiotic bacteria: The isolated Bacillus sp. was identified at its species level based on the microscopic, cultural and biochemical characteristics. ${ }^{11}$

Optimal temperature, $\mathrm{pH}$ and salinity for the antagonistic action of the probiotic bacteria: The optimal conditions for growth and production of antagonistic principle by Bacillus was assessed by growing the culture in $\mathrm{LB}$ broth at various temperatures $\left(25^{\circ} \mathrm{C}, 30^{\circ} \mathrm{C}, 35^{\circ} \mathrm{C}, 40^{\circ} \mathrm{C}\right.$ and $\left.45^{\circ} \mathrm{C}\right), \mathrm{pH}$ (6.0, 7.0, 7.5, 8.0 and 9.0) and salinities (0.5\% and $1 \%)$ in $100 \mathrm{ml}$ culture volumes at $150 \mathrm{rpm}$ for the period of 7 days in duplicates. Samples for cell count and antagonistic activity were drawn in $1^{\text {st }}, 3^{\text {rd }}, 5^{\text {th }}$ and $7^{\text {th }}$ day. One milliliter of the culture was processed for evaluating the antagonistic potential against a virulent strain of Vibrio sp., previously isolated from the shrimp rearing pond ${ }^{(12)}$ by disc- diffusion method. ${ }^{13}$ The cell counts were determined by taking the absorbance at $600 \mathrm{~nm}$.

Time course for the optimal antagonistic activity production: For the determination of time course for the optimal antagonistic activity of Bacillus, it was inoculated in $20 \mathrm{ml} \mathrm{LB}$ broth, $\mathrm{pH}$ and salinity of the medium adjusted at the respective optimal values and then incubated on a shaking incubator for 150 rotations per minute (rpm) at the optimized temperature. Samples for antagonistic activity were drawn on $1^{\text {st }}, 3^{\text {rd }}, 5^{\text {th }}, 7^{\text {th }}, 9^{\text {th }}$ and $10^{\text {th }}$ day and were processed for evaluating the antagonistic potential by the disc diffusion method as mentioned earlier. $^{13}$

Preliminary characterization of the antibacterial component in cell-free supernatant of the probiotic bacteria: The cell-free culture supernatant of Bacillus sp. containing the antibacterial principle was obtained from the culture grown under optimal conditions as mentioned earlier. It was treated with Triton X114 (10\%, 20\% \& 30\%), Tween 80 (10\%, 20\% \& 30\%), SDS (0.25 mM, 0.1 $\mathrm{mm}, 0.05 \mathrm{mM}$ and $0.01 \mathrm{mM})$, EDTA $(0.25 \mathrm{mM}, 0.1$ $\mathrm{mm}, 0.05 \mathrm{mM} \& 0.01 \mathrm{mM})$. After an overnight incubation, antibacterial activity against pathogenic Vibrio sp. along with appropriate controls was tested by the disc diffusion method.

\section{RESULTS AND DISCUSSION}

Identification of the selected probiotic bacteria: The isolated probiont, Bacillus sp. was presumptively identified as Bacillus licheniformis following their analysis by biochemical tests (Table 1) after comparing with the standards, as outlined in Bergey's Manual of Systematic Bacteriology. ${ }^{11}$

Optimum temperature for growth and antagonistic action of the probiont: Bacillus licheniformis is a mesophilic organism and is able to grow in a wide range of temperatures. Here, we observed that the antibacterial activity of the bacterium appears to be directly proportional to its growth. Its greatest vibriocidal activity and the highest growth both were recorded at $30^{\circ} \mathrm{C}$ with a 
maximum inhibitory zone of $16 \mathrm{~mm}$, observed on the $3^{\text {rd }}$ day of post-harvest (Figure $1 \mathrm{~A}$ and $\mathrm{B}$ ). At day 7 of bacterial growth, the activity decreased to $12 \mathrm{~mm}$ zone of clearance, an activity still considered to be significant to be a potential probiont.

Table 1. Biochemical characteristics of the probiont

\begin{tabular}{lc}
\hline Biochemical test & Reaction \\
\hline MR & + \\
VP & + \\
Indole & - \\
Citrate & + \\
Propionate & + \\
Gelatin liquefaction & + \\
Nitrate reduction & + \\
Oxidase & - \\
Catalase & + \\
Glucose fermentation & AG \\
Mannitol fermentation & + \\
Arabinose fermentation & + \\
Xylose fermentation & + \\
Lactose fermentation & + \\
Starch hydrolysis & + \\
\hline
\end{tabular}

AG: acid and gas from glucose fermentation; + denotes ability to ferment sugar.

Optimum pH for growth and antagonistic action of the probiont: The tested $\mathrm{pH}$ ranges did not result in significant variation in the growth of $B$. licheniformis or inhibitory activity except at pH 6 . The antagonistic activity was highest at $\mathrm{pH} 7.5$ after 3 days of cultivation with a clearing zone of $13 \mathrm{~mm}$ (Figure 2).

\section{Optimum salinity for growth and antagonistic} action of Bacillus: The tested salinities of 0.5 and $1.0 \%$ did not result in significant variation in the growth of Bacillus licheniformis. It showed optimum growth at $0.5 \%$ salinity, wherein, peak growth was attained after the 3rd day with concomitant maximum production of inhibitory metabolite. Antagonistic activity was observed after $72 \mathrm{~h}$ in the broth grown at salinities of $0.5 \%$ with a clearing zone of $16 \mathrm{~mm}$. (Figure 3).

Antagonistic action of $B$. licheniformis at the optimized conditions: Production of the antagonistic component was observed at the optimized conditions (i.e. $\mathrm{pH} 7.5,0.5 \%$ salinity and at $30^{\circ} \mathrm{C}$ ) right after the 24 hours of growth, which attained the peak after 72 hours post-harvest when the culture entered the late log phase, and the activity peaked in the stationary phase and remained stable thereafter, with only minor fluctuations in the activity (Figure 4).
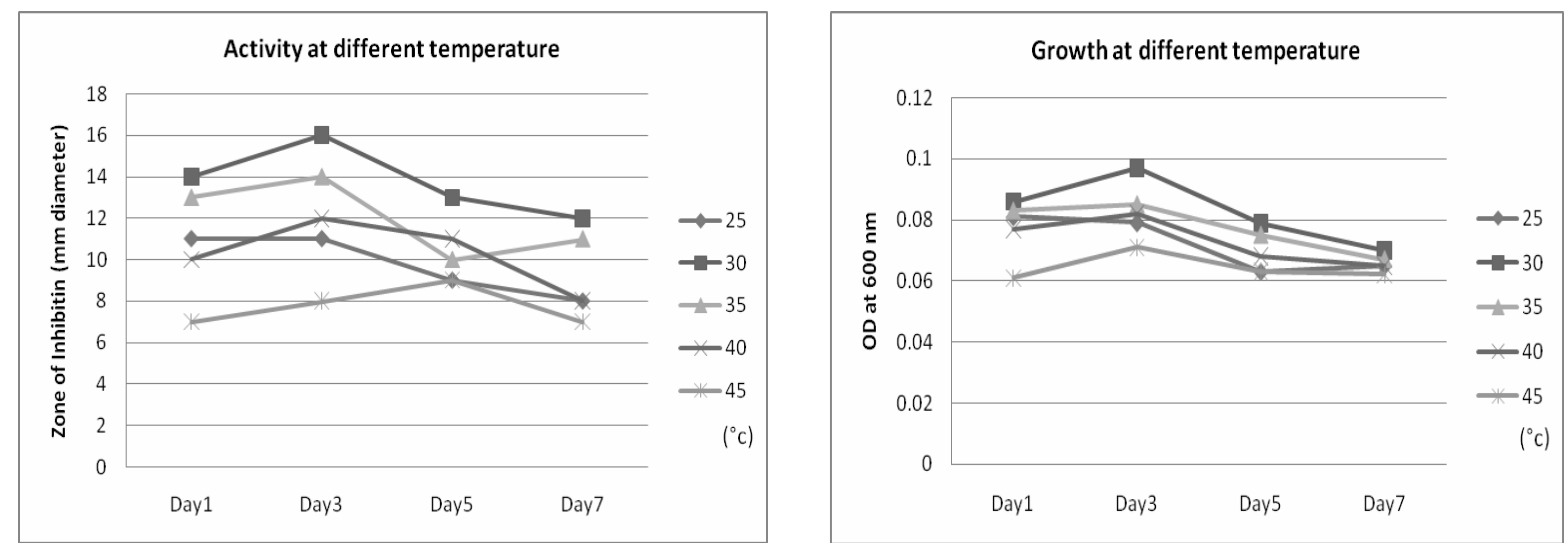

Figure 1. Optimum temperature for growth and antagonistic action of the probiont. B. licheniformis was harvested in nutrient broth at temperatures, 25, 30, 35, 40 and $45^{\circ} \mathrm{C}$; and culture supernatants were collected at days 1, 3, 5 and 7 post-harvest. The vibriocidal activity of $B$. licheniformis was tested in petridishes containing $50 \mu \mathrm{l}$ of cell-free extracts, absorbed in empty discs. The zone of inhibition produced around the discs against the growth of Vibrio sp., previously swabbed in the plate, after 48-hour incubation at $30^{\circ} \mathrm{C}$ is plotted in X-axis. A disc absorbed with the medium only was used as negative control that produced no inhibitory zone (A). The respective growth of $B$. licheniformis at different temperatures and at different time intervals was measured by taking absorbance at 600 $\mathrm{nm}(\mathrm{B})$. 

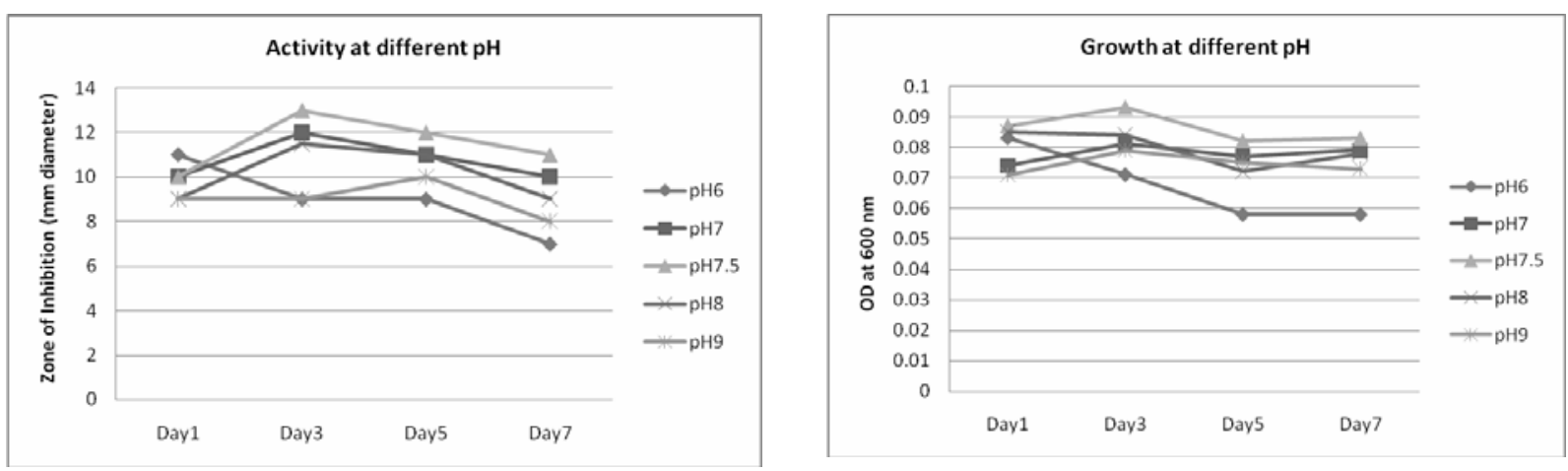

Figure 2. Optimum $\mathrm{pH}$ for growth and antagonistic action of the probiont. B. licheniformis was harvested in nutrient broth at $\mathrm{pH}, 6.0,7.0$, 7.5, 8.0 and 9.0; and culture supernatants were collected at days 1, 3, 5 and 7 post-harvest. The vibriocidal activity of B. licheniformis was tested by disc-diffusion method and is plotted in $\mathrm{X}$-axis (A). The respective growth of $B$. licheniformis at different $\mathrm{pH}$ and at different time intervals was measured by taking absorbance at $600 \mathrm{~nm}(\mathrm{~B})$.
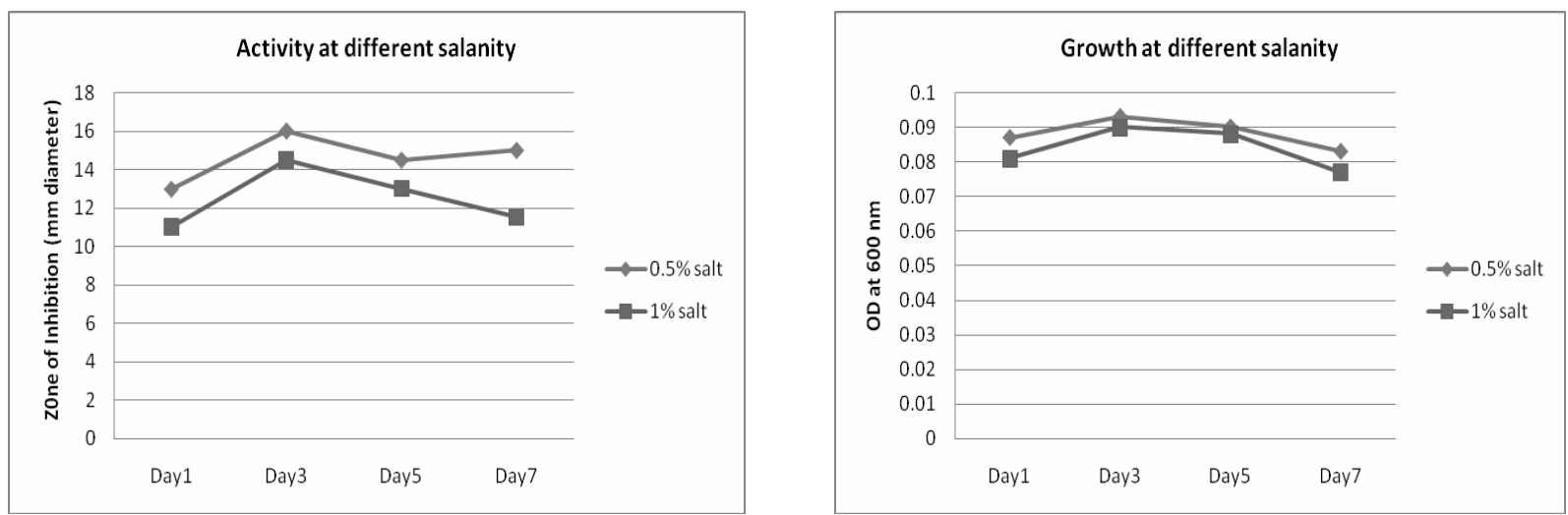

Figure 3. Optimum salinity for growth and antagonistic action of the probiont. B. licheniformis was harvested in nutrient broth at 0.5 and $1.0 \%$ salinitities; and culture supernatants were collected at days 1, 3, 5 and 7 post-harvest. Its vibriocidal activity was tested by discdiffusion method and is plotted in X-axis (A). The respective growth of B. licheniformis at different salinities and at different time intervals was measured by taking absorbance at $600 \mathrm{~nm}$ (B).

Partial characterization of the antibacterial component in cell-free supernatant of $B$. licheniformis: The cell-free supernatant was treated with Triton X114 (10\%, 20\% \& 30\%), Tween 80 (10\%, 20\% \& 30\%), SDS (0.1 mM, $0.05 \mathrm{mM} \& 0.01$ $\mathrm{mM})$, EDTA (0.1 mM, $0.05 \mathrm{mM} \& 0.01 \mathrm{mM})$. Then antibacterial activity against the target Vibrio was tested by the disc diffusion assay. While the extract alone produced a $7 \mathrm{~mm}$ zone of inhibition, the detergents- Triton X114, Tween 80 or SDS at their different concentrations also produced greater zones of inhibition around the discs even in absence of the extract, used as controls (Figure 5). Hence, their effects were refractory to the antibacterial component of the probiont. Treatment with the metal-chelating substance, EDTA however, nullified the antibacterial activity of B. licheniformis completely, at its 0.01 $\mathrm{mM}$ concentration; the lowest tested, a strength that does not produce any vibriocidal effect on its own; thereby indicating the requirement of a metal active group in the active fraction of the probiont's cell-free supernatant.

The current concern over the spread of antibiotic resistance genes due to indiscriminate use of antibiotics in the aquaculture industry, the failure to identify new antibiotics and the inherent problems with developing new vaccines make a compelling case for developing alternative prophylactics. The potential use of probiotics could open new avenue in combating this problem. In fact, the field of probiosis has emerged as a new science with applications in farming and aquaculture as alternatives to 
antibiotics. $^{2}$ To date, no study had been conducted in controlling bacterial infection in shrimps on farms in relation to probiotic usage in Bangladesh. A good number of probiotics, purchased from foreign origin, however were tested in some hatcheries and culture ponds of Khulna region, and was not found effective (personal communication). This observation therefore demands to discover new probiotics from the indigenous origin to be effective in local environment.

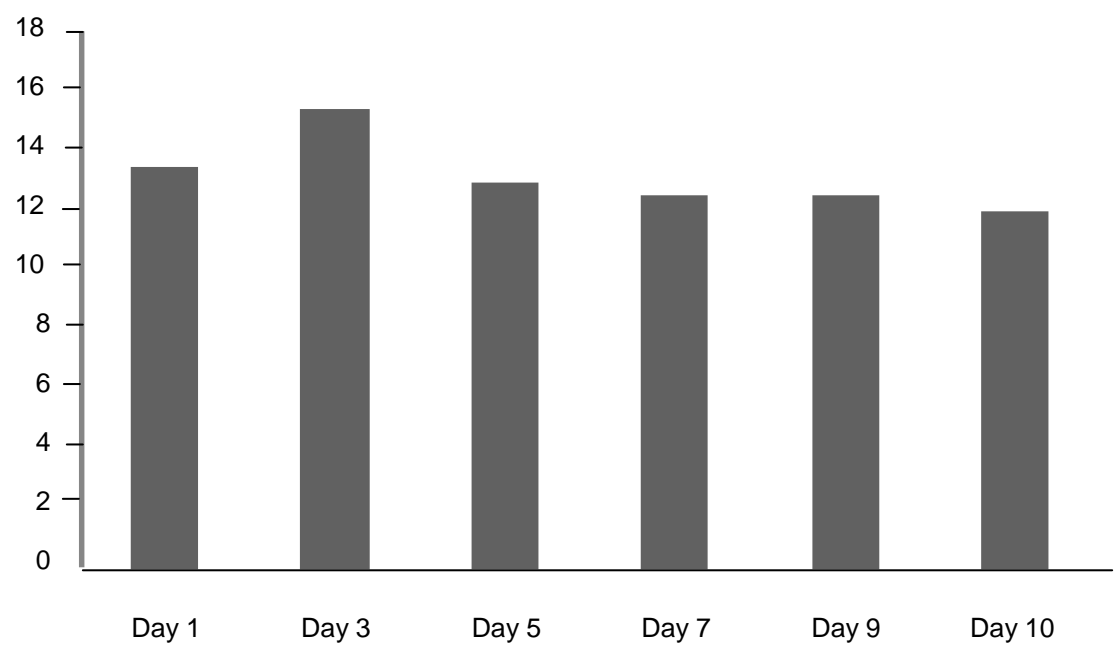

Figure 4. Optimization of the antagonistic action of the probiont. B. licheniformis was harvested at optimized conditions $\left(30^{\circ} \mathrm{C}, \mathrm{pH} 7.5\right.$ and at $0.5 \%$ salinity) for ten days. The culture was withdrawn as indicated time intervals to assess the vibriocidal activities of the respective cell-free extract by disc-diffusion assay.

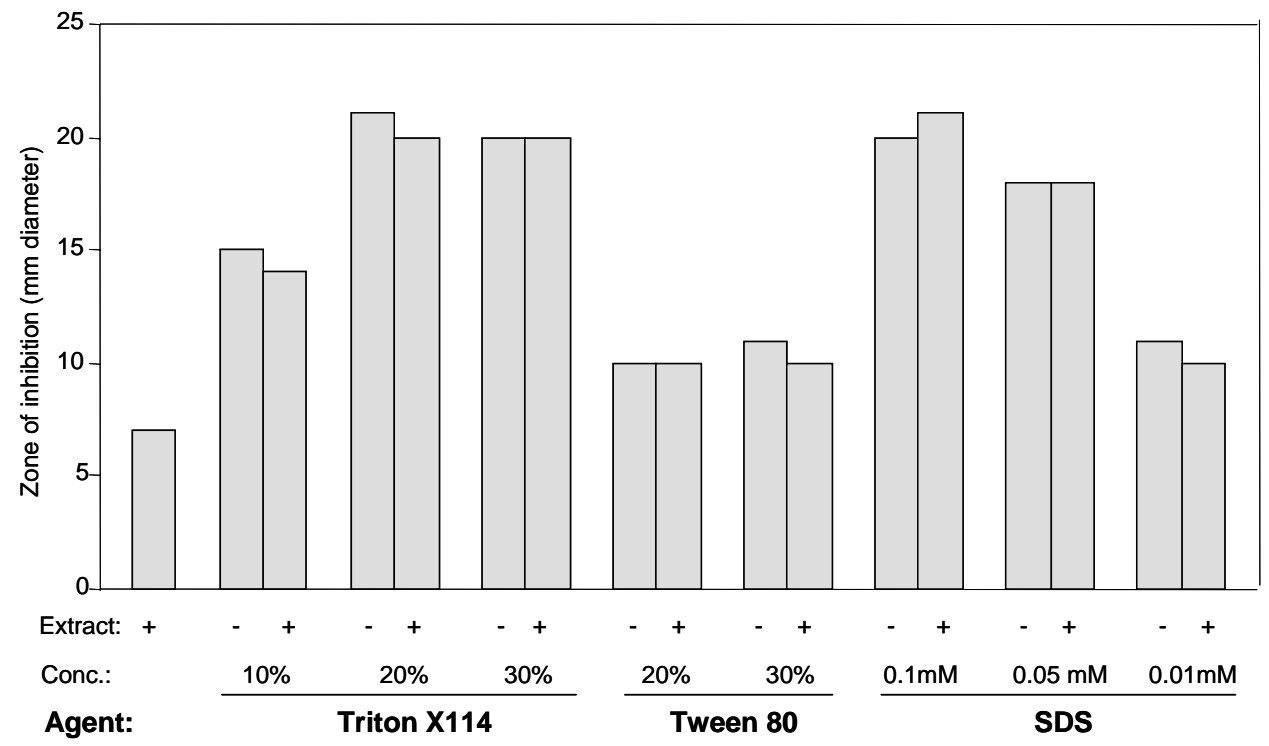

Figure 5. Partial characterization of the antagonistic action of cell-free supernatant (Extract) of B. licheniformis. Effects of detergents, viz. Triton X114, Tween 80, and SDS at their different concentrations (as indicated) are mixed with (+) or without (-) the extract of the probiont (Extract) in discs and then tested on the vibriocidal activity by disc-diffusion assay on a agar plate previously swabbed with the pathogenic Vibrio spp. Results are plotted in terms of the zone of inhibition produced around the discs. 
The results in this study show that $B$. licheniformis isolated from the rearing environment of shrimp aquaculture produced a wide zone of inhibition against several Vibrio sp. tested. The result of disc-diffusion method indicates that it is not the bacterial cell but an extracellular product that is likely to be responsible for inhibition. Likewise, Vijayan et al (2006) ${ }^{14}$ noted that a cell-free culture supernatant of a brackishwater isolate, Pseudomonas appeared as a potential antagonistic bacterium against pathogenic vibrios in penaeid and non-penaeid rearing systems. It can be suggested that $B$. licheniformis produces some extracellular anti-vibrio component. These results are very significant since $V$. harveyi is a great problem in shrimp hatcheries. One of the most important criteria for a candidate to be used in biocontrol is that the organism should be nonpathogenic to the host. Characterization of the inhibitory component in the cell-free extract of $B$. licheniformis suggests that it is a metal active grouprequiring extracellular substance that exhibit vibriocidal activity.

The maximum production of antivibrio factor was observed at $\mathrm{pH} 7.5$ (Figure 2) and at temperature of $30-37^{\circ} \mathrm{C}$ (Figure 1) which was also the optimum $\mathrm{pH}$ and temperature for the growth of the organism. This suggests a close relation between growth of $B$. licheniformis and production of antivibrio factor. This is further confirmed by results in Figure 3, which show that production of antivibrio factor was the highest at a $\mathrm{NaCl}$ concentration of $0.5 \%$ which was optimal for growth of the organism. The appearance of the antivibrio activity in the medium when the cells reach stationary phase of growth and maximum activity at late stationary phase (Figures 13) suggests that the antivibrio factor is a secondary metabolite. This activity of the isolate was found evident in a wide range of environmental tolerance: temperatures from $25^{\circ} \mathrm{C}$ to $40^{\circ} \mathrm{C}$, pH from 6 to 8 , and salinity from $0.5 \%$ to $1 \%$. Further, when the isolate was grown in the optimized environmental conditions, i.e. at $30^{\circ} \mathrm{C}, \mathrm{pH} 7.5$ and at $0.5 \%$ salinity, the antagonistic activity rose at its peak in 3 days, and remained significantly active even at the $10^{\text {th }}$ day of post-harvest (Figure 4). In conclusion, it can be stated that the isolate of $B$. licheniformis has the properties of a biocontrol agent for use in shrimp hatcheries and farms.

Probiotic treatment offers a promising alternative to the antibiotics for fish and shrimp aquaculture system. Since probiotics are made from natural mechanisms, shrimp farmers who learn to farm microorganisms will be far more likely to achieve successful harvests. Therefore, the probiotic bacteria, isolated from this study might have the potentiality to control the shrimp larval pathogens and may substitute the use of antibiotics in aquaculture, once it successfully passes the safety tests.

\section{ACKNOWLEDGEMENTS}

The financial supports of "University Grants Commission, Bangladesh" and "Biotechnology Research Centre”, University of Dhaka, Dhaka, Bangladesh in conducting the study are gratefully acknowledged.

\section{REFERENCES}

1. Baticados, M.C.L., Lavilla-Pitogo, C.R., Cruz-Lacierda, E.R., De La Pena, L.D. and Sunaz, N.A. 1990. Studies on the chemical control of luminous bacteria Vibrio harveyi and $V$. splendidus isolated from diseased Penaeus monodon larvae and rearing water. Dis. Aquat. Org. 9, 133-139.

2. Moriarty, D.J.W. 1999. Disease control in shrimp aquaculture with probiotic bacteria. In CR Bell, M Brylinsky and P Johnson-Green (eds.) Microbial biosystems; new frontier. Proceedings of $8^{\text {th }}$ International Symposium on Microbial Ecology. Atlantic Canada Society for Microbial Ecology, Halifax, Canada.

3. Murray, G.E., Tobin, R.S., Junkins, B. and Kushner, D.J. 1984. Effect of chlorination of antibiotic resistance profiles of sewage related bacteria. Appl. Environ. Microbiol. 48, 7377.

4. Irianto, A. and Austin, B. 2002. Probiotics in aquaculture. $J$. Fish Dis. 25, 633-42.

5. The Daily Star Internet Edition. May 20, 2009.

6. Verschuere, L., Rombaut, G., Sorgeloos, P. and Verstraere, W. 2000. Probiotic bacteria as biological control agents in aquaculture. Microbiol. Mol. Biol. Rev. 64, 655-671.

7. Rahman, S., Khan, S.N., Naser, M.N. and Karim, M.M. 2009. Application of probiotic bacteria: a novel approach towards ensuring food safety in shrimp aquaculture. $J$. Bangladesh Acad. Sci. 33, 139-144. 
8. Sambasivam, S., Chandran, R. and Khan, S.A. 2003. Role of probiotics on the environment of shrimp pond. J. Environ. Biol. 24, 103- 106.

9. Sarker, A., Khan, S.N., Naser, M.N. and Karim, M.M. 2008. Isolation of probiotic bacteria from natural sources to control diseases in shrimp aquaculture. In: Food Safety and Hygiene. Choudhury, N., Ahsan, C.R. and Karim, M.M. (eds.), Bangladesh Academy of Sciences, Bangladesh. pp 129-135.

10. Sharmilla, R., Jawahar Abraham, T. and Sundararaj, V. 1996. Bacterial flora of semi-intensive pond reared Penaeus indicus (Milnc Edwards, H.) and the environment. J. Aquaculture in the tropics. 11, 193-203.

11. Rabinowitz, J.C. and Roberts, M. 1996. Translational barriers limiting expression of E. coli genes in Bacillus and other Gram positive organisms. In: Levy, S.V. and Novick, R.P. (eds) Banbury report 24; Antibiotic Resistance Genes: Ecology, Transfer and Expression, Cold Spring Harbor Laboratory, pp. 297-312.
12. Krieg, N.R. and Holt, J.G. 1984. Bergey's Manual of Systematic Bacteriology, Vol 1, Williams and Wilkins, Baltimore, USA. pp. 140-219.

13. Sarker, A. 2005. Isolation and partial characterization of probiotic bacteria as a biocontrol agent against vibrios in shrimp aquaculture. MS thesis, Department of Microbiology, University of Dhaka, Dhaka.

14. Vaseeharan, B. and Ramasamy, P. 2003. Control of pathogenic Vibrio spp. by Bacillus subtilis BT23, a possible probiotic treatment for black tiger shrimp Penaeus monodon. Lett Appl Microbiol. 36, 83-87.

15. Vijayan, K.K., Singh, I.S.B., Jayaprakash, N.S., Alavandi, S.V., Pai, S.S., Preetha, R., Rajan, J.J.S. and Santiago, T.C. 2006. A brackishwater isolate of Pseudomonus PS-102, a potential antagonistic bacterium against pathogenic vibrios in penaeid and non-penaeid rearing systems. Aquaculture 251, 192-200. 